\title{
A STUDY ON CONSUMER PERCEPTION TOWARDS CHALLENGES OF DIGITAL MARKETING
}

\author{
Dr. Mrinal Phalle ${ }^{1}$, Dr. Vaishali Patil ${ }^{2}$ and Ms. Janhavi Chapade ${ }^{3}$ \\ ${ }^{1}$ Associate Professor, SGPC's Guru Nanak Institute of Management Studies, Matunga, Mumbai \\ ${ }^{2}$ Senior Associate Dean, Research \& Publications \& IT, Prin.L. N. Welingkar Institute of \\ Management Development \& Research , Mumbai \\ ${ }^{3}$ PGDM Student, SGPC's GNIMS, Matunga, Mumbai
}

\begin{abstract}
Worldwide technology has changed a type of marketing techniques that embeds the company's brand and product on digital platforms. Digital marketing has become important fulcrum for business organizations giving access to the mass market at an affordable price. The objective behind the present study is to analyze awareness level as well as challenges faced in digital marketing. The survey has been conduct at Mumbai city. Descriptive Study was conducted to analyses response of consumer towards digital marketing and factor analysis was carried out to identify major challenges of digital marketing. It is open from the present study that major challenges faced in digital marketing are lack of adequate skills and training to employees, technology, security and creative content for increasing awareness towards digital marketing. Further the study suggests that to ensure success of digital marketing staff should be well trained so that they have the right knowledge and expertise to handle new tools, platforms and trends as they change rapidly. Further to enhance the access of digital marketing in India more prominence needs to give on improving infrastructure facilities and awareness of the digital marketing as a cost-effective way of marketing.
\end{abstract}

KEYWORDS: Digital marketing, Perception, Challenges

Article Received: 10 August 2020, Revised: 25 October 2020, Accepted: 18 November 2020

\subsection{INTRODUCTION}

Digital showcasing keeps on developing expanding its hang on the worldwide piece of the overall industry of the whole publicizing market, with advanced promoting market anticipated to arrive at US4185.4 billion by 2023. Agreeing the Global Entertainment and Media standpoint 2017-2023 report by PWC, to help us start to comprehend the eventual fate of the advertising business. In term of the more extensive promoting industry, and furthermore significantly, the effect it will have on our individual occupation jobs. In 2023 the market will US\$185.4 billion around the world. This is a stunning $29 \%$ portion of the all out worldwide promoting market. At a development of more than $13 \%$ over only five years this makes it the second greatest spend after TV. Henceforth it is important to examine impression of buyers towards advanced showcasing.

\subsection{LITERATURE REVIEW}

Web Marketing has been portrayed essentially as accomplishing advertising goals through applying computerized innovations by Chaffee, D. (2007). Burrett (2008) comprehends internet advertising as cautiously focusing on clients to connect with companies while they were locked in the nearest proximity to home, personal medium at any point imagined. Chaffey D and Smith P (2008) basically characterize web advertising as "the utilization of the web and related advanced innovations to accomplish showcasing objectives. According to Kotler (2014) webbased advertising comprises of measures and exercises to advance items and administrations and fabricate associations with clients over the Internet. Allen, E. what's more, Fjermestad, J. (2001) exhibited the convenience of the conventional promoting model in creating online business advertising procedures to a genuine organization utilizing the incorporated model.

However, Dahiya \& Gayatri (2017) suggested that costumers satisfied towards advanced correspondence to get influenced from other consumers audits and share their after purchase sentiments over computerized stages. Not with standing, the investigation additionally affirmed that despite the fact that clients value the use of advanced channels all 
through the dynamic excursion, still they don't book a vehicle on the web. P. Sathya (2017) concentrated on the size of advanced advancement for the two clients and advertisers and tracked down that computerized promoting has end up being vital piece of approach of numerous organizations. As per Gangeshwer, (2013) digital advertising advances license the clients to stay with on with the data think. P.K.Kannan et al. (2017) inspected the issues in advanced promoting from the point of view of the firm and discovered innovation as a significant issue. Further Mrs. Vaibhava Desai (2019) focused on theoretical comprehension of advanced promoting, how computerized advertising helps the present business and a few cases as specific illustrations. Andrew Parsons (1998) was built up an incorporated viewpoint on utilizing intuitive media for advertising, which we allude to as computerized promoting. Afrina Yasmin et al. (2015) studied various types of computerized showcasing, viability as well as its impact on company's deals. The analyzed example comprises of 150 firms and 50 chiefs which randomly selected to demonstrate the adequacy of modern advertising.

In the year 2000 the Giese and Gote found that client data fulfillment for advertising can be hypothesized as an amount of emotional reaction of changing force. Its utilization and is invigorated by central parts of deals exercises, data frameworks, advanced administrations, client assistance, after-deals administration and friends culture. Vishal Midha in year 2012 inspected discernment's between the sexes vary concerning purchaser strengthening and protection concerns and found that strengthening has a more grounded beneficial outcome on trust for guys than for females, and that security concerns adversely affect trust for females than for males. As per the above open writing accessible exploration done in computerized promoting is restricted to just not many specific territories, like computerized showcasing mindfulness and acknowledgment on the lookout. Yet, there an uncommon investigation has been directed on advanced showcasing inclination, mentality and view of purchaser. To satisfy this hole present examination embraced an exploration on mindfulness, discernment and difficulties of computerized promoting.

\subsection{RESEARCH METHODOLOGY}

\section{Objectives}

The following are the objectives of present work;

a. To understand consumer perception level towards digital marketing.

b. To identify challenges of digital marketing in Indian Market.

\section{RESEARCH METHODOLOGY}

The principle instrument that is utilized for information assortment is survey. As indicated by Saunders, Lewis and Thornhill (2009), a survey alludes to the overall term including all information assortment strategies in which an individual is approached to answer similar arrangement of inquiries in a foreordained order. Survey strategy was utilized for information assortment from buyers. The survey has been conducted in Mumbai metropolitan city of Maharashtra of 100 respondents. The comfort testing procedure was utilized and information has been gathered from essential just as optional information. Essential information was gathered through survey. Questionnaire is framed by using Likert scale with five point rating was utilized to quantify the responses on challenges of digital marketing. The reactions to the various inquiries have been addressed utilizing enlightening measurements to the variable being scrutinized. The optional information was taken from the exploration papers, books, articles different sites and so forth Factor investigation has been never really up the various variables that are viewed as significant in use of advanced showcasing. ANOVA and t-test was conducted utilized to decide whether there are huge contrasts in the mean scores for demographic factors like gender, age and income towards challenges of digital marketing.

\subsection{HYPOTHESIS}

Following theory are tested to find out observation of respondents in the direction of digital marketing

H0: For the demographic factors no critical contrast in mean on impression towards digital marketing

H1: For the demographic factors critical contrast in mean on impression towards digital marketing 


\subsection{RESULTS AND DISCUSSIONS:}

\section{A) Awareness Amongst Consumers}

The information has been investigated utilizing enlightening measurements. 60 respondents were male which is 60 percent and 40 percent were female respondents from 100 respondent. The greater parts of the respondents are from bunch of 20-30 years which is 62 percent. The maximum respondents which are $50 \%$ and less than $25 \mathrm{yrs}$ of age, $40 \%$ are $25-45 \mathrm{yrs}$ of age and $10 \%$ are more than 45 yrs of age. $50 \%$ are less than 1000000 of annual income, $40 \%$ are 1000000-3000000 and 10\% are more than 3000000 of annual Income. $70 \%$ of respondent are responsive of digital marketing and $30 \%$ are not aware of digital marketing. Further study shows that $57 \%$ of the respondents are doing digital marketing from more than 2 years. Further results shows that $36 \%$ of companies are using Social Media Marketing for promoting their product/services, $22 \%$ of companies are using Search Engine Optimization, $14 \%$ are using Email/ENewsletter making, $10 \%$ are using Text(SMS) marketing, $8 \%$ are using forums/communities/ flash demos/ blogs, 6\% are using Pay Per Click and rest $4 \%$ of companies are doing nothing specific but interested. 36\% of their companies are using both in house team and outside Agency for Managing digital marketing, $28 \%$ of their companies are using In house Team, 20\% are using outside agency and other 16\% are looking for Agency.

\section{B) Major challenges faced in Digital marketing:}

Factor investigation has been done to amount of the major challenges that are measured vital use of digital marketing.

\section{Kaiser Meyer Olkin and Bartlett's Test of sphericity:}

We use the technique of factor investigation to find out which challenges pressure the usage of digital marketing. Eleven variables are used for analysis of challenges of digital marketing. To examine the correctness of factor analysis we used Bartlett's test of sphericity and Kaiser-Meyer Olkin measures of sampling adequacy. The appropriate chi-square statistic is 372.548 with 55 degrees of freedom, which is 0.00 levels (as presented in Table 1). The KMO statistics (0.568) is considerable $(>0.5)$. Hence factor investigation is considered an appropriate method for further analysis of data.

Table No. 1: Test result of KMO and Bartlett's

\begin{tabular}{|c|c|c|}
\hline \multicolumn{2}{|c|}{ Kaiser-Meyer-Olkin Measure of Sampling Adequacy. } & 0.568 \\
\hline \multirow{3}{*}{ Bartlett's Test of Sphericity } & Approx. Chi-Square & 372.548 \\
\cline { 2 - 3 } & Degree of freedom & 55 \\
\cline { 2 - 3 } & Significant value & 0.000 \\
\hline
\end{tabular}

\begin{tabular}{|c|c|c|c|c|c|c|c|c|c|}
\hline \multicolumn{10}{|c|}{ Total Variance Explained (Table No.2) } \\
\hline \multirow[b]{2}{*}{ Component } & \multicolumn{3}{|c|}{ Initial Eigen values } & \multicolumn{3}{|c|}{$\begin{array}{c}\text { Extraction Sums of Squared } \\
\text { Loadings }\end{array}$} & \multicolumn{3}{|c|}{$\begin{array}{c}\text { Rotation Sums of Squared } \\
\text { Loadings }\end{array}$} \\
\hline & Total & $\begin{array}{c}\text { Percentage } \\
\text { of } \\
\text { Variance }\end{array}$ & $\begin{array}{l}\text { Cumulative } \\
\text { Percentage }\end{array}$ & Total & $\begin{array}{c}\text { Percentage } \\
\text { of } \\
\text { Variance } \\
\end{array}$ & \begin{tabular}{|l|} 
\\
Cumulative \\
Percentage
\end{tabular} & Total & $\begin{array}{c}\text { Percentage } \\
\text { of } \\
\text { Variance } \\
\end{array}$ & $\begin{array}{l}\text { Cumulative } \\
\text { Percentage } \\
\end{array}$ \\
\hline 1 & 3.779 & 34.352 & 34.352 & 3.779 & 34.352 & 34.352 & 2.958 & 26.888 & 26.888 \\
\hline 2 & 1.866 & 16.966 & 51.318 & 1.866 & 16.966 & 51.318 & 2.640 & 24.004 & 50.892 \\
\hline 3 & 1.591 & 14.466 & 65.784 & 1.591 & 14.466 & 65.784 & 1.461 & 13.284 & 64.176 \\
\hline 4 & 1.076 & 9.780 & 75.564 & 1.076 & 9.780 & 75.564 & 1.253 & 11.388 & 75.564 \\
\hline 5 & 0.732 & 6.657 & 82.221 & & & & & & \\
\hline 6 & 0.677 & 6.151 & 88.372 & & & & & & \\
\hline 7 & 0.508 & 4.615 & 92.987 & & & & & & \\
\hline 8 & 0.368 & 3.343 & 96.330 & & & & & & \\
\hline 9 & 0.205 & 1.863 & 98.193 & & & & & & \\
\hline
\end{tabular}




\begin{tabular}{|l|c|c|c|l|l|l|l|l|l|}
\hline 10 & 0.114 & 1.036 & 99.229 & & & & & & \\
\hline 11 & 0.085 & 0.771 & 100.000 & & & & & & \\
\hline
\end{tabular}

From above table no. 2 it has been seen that underlying eigen esteems just four factors are more prominent than 1. From total 11 variables we have reduced to 4 factors. Further Sums of Squared Loadings Cumulative is more noteworthy than 60 percent. So we can make the factors. There are four factors are identified as demonstrated in Table No.3.Thus after rotation $1^{\text {st }}$ factor trained staff account for $26.888 \%$ of variation in data. $2^{\text {nd }}$ factor accounts for technology $24.004 \%$ of variation in data. $3^{\text {rd }}$ factor Access to the creative content account for $13.284 \%$ of variation in data. $4^{\text {th }}$ factor Security account for $11.388 \%$ of variation in data as shown in Table No.3.

\begin{tabular}{|l|c|c|c|c|}
\hline Rotated Component Matrix (Table No.3) & \multicolumn{4}{|c|}{ Component } \\
\cline { 2 - 5 } & 1 & 2 & 3 & 4 \\
\hline Learning about customers & 0.824 & 0.149 & -0.253 & 0.033 \\
\hline Generating Qualified Leads & -0.107 & 0.904 & 0.015 & -0.047 \\
\hline Managing Cashflow & 0.906 & 0.105 & 0.256 & -0.072 \\
\hline Creating Engaging Content & 0.191 & 0.321 & 0.621 & 0.029 \\
\hline Complying with Privacy \& Data sharing Regulation & -0.238 & 0.680 & -0.385 & 0.875 \\
\hline Training the Team & 0.651 & 0.418 & 0.094 & -0.117 \\
\hline Making Website Accessible & 0.154 & 0.774 & -0.037 & 0.476 \\
\hline Strategizing Mobile first & 0.156 & 0.804 & -0.038 & 0.032 \\
\hline Maintaining Brand Consistency and Authority & 0.122 & -0.145 & -0.072 & -0.325 \\
\hline Understanding Tools and Technology & 0.610 & 0.228 & 0.324 & 0.321 \\
\hline Establishing an Omnichannel Marketing Strategy & -0.807 & -0.131 & 0.361 & -0.169 \\
\hline
\end{tabular}

\section{C) Perception of customers towards} challenges of digital marketing

The $\mathrm{t}$-test has been used to find out if there are significant differences in the mean for gender (male and female), age (younger and older).
ANOVA has been used to determine if there is a significant difference in the mean for income on perception of customers towards challenges of digital marketing.

\section{Gender:}

Table no. 4: Test of equality of variance

\begin{tabular}{|c|c|c|c|c|}
\hline Factor & Hypothesis & $\begin{array}{c}\mathrm{P}- \\
\text { value }\end{array}$ & Decision & Interpretation \\
\hline Trained staff & $\begin{array}{l}H_{o}: \sigma_{m}^{2}=\sigma_{f}^{2} \\
H_{1}: \sigma_{m}^{2} \neq \sigma_{f}^{2}\end{array}$ & 0.415 & $\begin{array}{l}P \text { value }>\alpha \\
\text { Accept } H_{0}\end{array}$ & $\begin{array}{l}\text { Variance for both male and female } \\
\text { respondents have same perception on Trained } \\
\text { staff }\end{array}$ \\
\hline Technology & $\begin{array}{l}H_{o}: \sigma_{m=\sigma_{f}^{2}}^{2} \\
H_{1}: \sigma_{m}^{2} \neq \sigma_{f}^{2}\end{array}$ & 0.301 & $\begin{array}{l}P \text { value }>\alpha \\
\text { Accept } H_{0}\end{array}$ & $\begin{array}{l}\text { Variance for both male and female } \\
\text { respondents have same perception on } \\
\text { Technology }\end{array}$ \\
\hline $\begin{array}{l}\text { Creative } \\
\text { Content }\end{array}$ & $\begin{array}{l}H_{o}: \sigma_{m}^{2}=\sigma_{f}^{2} \\
H_{1}: \sigma_{m}^{2} \neq \sigma_{f}^{2}\end{array}$ & 0.677 & $\begin{array}{l}P \text { value }>\alpha \\
\text { Accept } H_{0}\end{array}$ & $\begin{array}{l}\text { Variance on gender have same perception on } \\
\text { Creative Content }\end{array}$ \\
\hline Security & $\begin{array}{l}H_{0}: \sigma_{m}^{2}=\sigma_{f}^{2} \\
H_{1}: \sigma_{m}^{2} \neq \sigma_{f}^{2}\end{array}$ & 0.645 & $\begin{array}{l}\text { P value }>\alpha \\
\text { Accept } H_{0}\end{array}$ & $\begin{array}{l}\text { Variance on gender have same perception on } \\
\text { Security }\end{array}$ \\
\hline
\end{tabular}

Table no. 4 shows that variances are equal for all factors on account of gender respondents. 
Table no. 5: Independent t-test

\begin{tabular}{|c|c|c|c|l|l|}
\hline Factor & Hypothesis & $\begin{array}{c}\text { P- } \\
\text { value }\end{array}$ & Decision & Interpretation \\
\hline Trained staff & $\begin{array}{l}\mathrm{H}_{\mathrm{o}}: \mu_{\mathrm{m}}=\mu_{\mathrm{f}} \\
\mathrm{H}_{\mathrm{f}}: \mu_{\mathrm{m}} \neq \mu_{\mathrm{f}}\end{array}$ & 0.562 & $\begin{array}{l}\text { P value }>\alpha \\
\text { Accept } \mathrm{H}_{\mathrm{o}}\end{array}$ & $\begin{array}{l}\text { Views of male client and female client are } \\
\text { same customer on Trained staff. }\end{array}$ \\
\hline Technology & $\begin{array}{l}\mathrm{H}_{\mathrm{o}}: \mu_{\mathrm{m}}=\mu_{\mathrm{f}} \\
\mathrm{H}_{\mathrm{f}}: \mu_{\mathrm{m}} \neq \mu_{\mathrm{f}}\end{array}$ & 0.609 & $\begin{array}{l}\text { P value }>\alpha \\
\text { Accept } \mathrm{H}_{\mathrm{o}}\end{array}$ & $\begin{array}{l}\text { Views of male client and female } \\
\text { respondents are same respondents on } \\
\text { Technology }\end{array}$ \\
\hline $\begin{array}{c}\text { Creative } \\
\text { Content }\end{array}$ & $\begin{array}{l}\mathrm{H}_{\mathrm{o}}: \mu_{\mathrm{m}}=\mu_{\mathrm{f}} \\
\mathrm{H}_{1}: \mu_{\mathrm{m}} \neq \mu_{\mathrm{f}}\end{array}$ & 0.507 & $\begin{array}{l}\text { P value }>\alpha \\
\text { Accept } \mathrm{H}_{\mathrm{o}}\end{array}$ & $\begin{array}{l}\text { Views of male client and female } \\
\text { respondents are same respondents on } \\
\text { Creative Content }\end{array}$ \\
\hline Security & $\begin{array}{l}\mathrm{H}_{\mathrm{o}}: \mu_{\mathrm{m}}=\mu_{\mathrm{f}} \\
\mathrm{H}_{1}: \mu_{\mathrm{m}} \neq \mu_{\mathrm{f}}\end{array}$ & 0.773 & $\begin{array}{l}\text { P value }>\alpha \\
\text { Accept } \mathrm{H}_{\mathrm{o}}\end{array}$ & $\begin{array}{l}\text { Views of male client and female } \\
\text { respondents are same respondents on } \\
\text { Security }\end{array}$ \\
\hline
\end{tabular}

We conclude that perception of male consumers is same as the female respondents for every one of the elements and from the engaging measurements additionally we are seen that estimation of mean score for male and female are by and large near one another from above Table no. 5 .

Age:

Table no. 6: Test of equality of variance

\begin{tabular}{|c|c|c|c|c|}
\hline Factor & Hypothesis & P-value & Decision & Interpretation \\
\hline Trained staff & $\begin{array}{l}H_{0}: \sigma_{y}^{2}=\sigma_{o}^{2} \\
H_{1}: \sigma_{y}^{2} \neq \sigma_{o}^{2}\end{array}$ & 0.031 & $\begin{array}{l}\mathrm{P} \text { value }<\alpha \\
\text { Accept } \mathrm{H}_{1}\end{array}$ & $\begin{array}{l}\text { Both younger and older respondents } \\
\text { variance are not same on Trained staff }\end{array}$ \\
\hline Technology & $\begin{array}{l}H_{0}: \sigma_{y}^{2}=\sigma_{o}^{2} \\
H_{1}: \sigma_{y}^{2} \neq \sigma_{o}^{2}\end{array}$ & 0.202 & $\begin{array}{l}\text { P value }>\alpha \\
\text { Accept } H_{0}\end{array}$ & $\begin{array}{l}\text { Both younger and older respondents } \\
\text { variance are same on Technology }\end{array}$ \\
\hline $\begin{array}{l}\text { Creative } \\
\text { Content }\end{array}$ & $\begin{array}{l}H_{0}: \sigma_{y}^{2}=\sigma_{o}^{2} \\
H_{1}: \sigma_{y}^{2} \neq \sigma_{o}^{2}\end{array}$ & 0.249 & $\begin{array}{l}\text { P value }>\alpha \\
\text { Accept } H_{0}\end{array}$ & $\begin{array}{l}\text { Both younger and older respondents } \\
\text { variance are same on Creative Content }\end{array}$ \\
\hline Security & $\begin{array}{l}H_{0}: \sigma_{y}^{2}=\sigma_{o}^{2} \\
H_{1}: \sigma_{y}^{2} \neq \sigma_{o}^{2}\end{array}$ & 0.356 & $\begin{array}{l}\text { P value }>\alpha \\
\text { Accept } H_{0}\end{array}$ & $\begin{array}{l}\text { Both younger and older respondents } \\
\text { variance are same on Security }\end{array}$ \\
\hline
\end{tabular}

Table no. 6 shows that we can wrap up that variances are equal for two factors except on potential benefits for younger and the older respondents.

Table no. 7: Independent t-test

\begin{tabular}{|c|c|c|c|l|}
\hline Parameter & Hypothesis & P-value & Decision & Interpretation \\
\hline Trained staff & $\begin{array}{l}\mathrm{H}_{\mathrm{o}}: \mu_{\mathrm{y}}=\mu_{\mathrm{o}} \\
\mathrm{H}_{1}: \mu_{\mathrm{y}} \neq \mu_{\mathrm{o}}\end{array}$ & 0.918 & $\begin{array}{c}\text { P value }>\alpha \\
\mathrm{H}_{\mathrm{o}} \text { Accepted }\end{array}$ & $\begin{array}{l}\text { Views of consumers are same across age } \\
\text { group on Trained staff. }\end{array}$ \\
\hline Technology & $\begin{array}{l}\mathrm{H}_{\mathrm{o}}: \mu_{\mathrm{y}}=\mu_{\mathrm{o}} \\
\mathrm{H}_{1}: \mu_{\mathrm{y}} \neq \mu_{\mathrm{o}}\end{array}$ & 0.124 & $\begin{array}{c}\text { P value }>\alpha \\
\mathrm{H}_{\mathrm{o}} \text { Accepted }\end{array}$ & $\begin{array}{l}\text { Views of consumers are same across age } \\
\text { group on Technology }\end{array}$ \\
\hline $\begin{array}{c}\text { Creative } \\
\text { Content }\end{array}$ & $\begin{array}{l}\mathrm{H}_{\mathrm{o}}: \mu_{\mathrm{y}}=\mu_{\mathrm{o}} \\
\mathrm{H}_{1}: \mu_{\mathrm{y}} \neq \mu_{\mathrm{o}}\end{array}$ & 0.324 & $\begin{array}{c}\text { P value }>\alpha \\
\mathrm{H}_{\mathrm{o}} \text { Accepted }\end{array}$ & $\begin{array}{l}\text { Views of consumers are same across age } \\
\text { group on Creative Content }\end{array}$ \\
\hline Security & $\begin{array}{l}\mathrm{H}_{\mathrm{o}}: \mu_{\mathrm{y}}=\mu_{\mathrm{o}} \\
\mathrm{H}_{1}: \mu_{\mathrm{y}} \neq \mu_{\mathrm{o}}\end{array}$ & 0.015 & $\begin{array}{c}\text { P value }>\alpha \\
\mathrm{H}_{1} \text { Accepted }\end{array}$ & $\begin{array}{l}\text { Views of youngrespondent are not same as } \\
\text { the older respondents on Security. }\end{array}$ \\
\hline
\end{tabular}

From above Table no. 7 we warp up that perception shows that estimation of mean insight on trained staff, Technology and Creative Content are same and contrasts on Security for the more youthful and more score for more youthful and more seasoned respondents are for the most part near one another. established respondents. An unmistakable Income: 
Table no. 8: ANOVA

\begin{tabular}{|l|l|c|c|c|c|c|}
\hline \multicolumn{2}{|c|}{} & Sum of Squares & df & Mean Square & F & Sig \\
\hline \multirow{3}{*}{ Trained staff } & Between Group & 3.65 & 3.0 & 1.21 & 1.22 & .35 \\
\cline { 2 - 7 } & Within Group & 83.34 & 84.0 & .99 & & \\
\cline { 2 - 7 } & Total & 87.00 & 87.0 & & & \\
\hline \multirow{3}{*}{ Technology } & Between Group & 3.64 & 3.0 & 1.21 & 1.22 & .35 \\
\cline { 2 - 7 } & Within Group & 83.33 & 84.0 & .99 & & \\
\cline { 2 - 7 } Creative & Total & 87.00 & 87.0 & & & \\
\hline \multirow{2}{*}{ Sontent } & Between Group & 4.51 & 3.0 & 1.50 & 1.53 & .01 \\
\hline & Within Group & 82.48 & 84.0 & .98 & & \\
\cline { 2 - 8 } & Total & 87.00 & 87.0 & & & \\
\hline
\end{tabular}

From above Table no. 8 we conclude that there is no significant difference in mean on perception of customers on account of income towards digital marketing for three factors trained staff, Technology and Security. Result of the above table shows that there is great significant differences in mean on awareness of respondents on account of income towards Creative content as a challenge for usage of digital marketing.

\subsection{CONCLUSION}

The improvement in technology fosters comprehensive opportunities and at the same unique challenge for the marketers. Marketers make use of high-quality digital marketing as display marketing place to promote a highly professional brand by defining the quality product in a smart manner that provides additional creditability. Further digital marketing consents enough provisions for identifying the right people through various social media marketing and with networking. In the present era, buyer expects knowledge that offers potential solution to their product related problem. The strong visibility of the organizations or the brand through digital marketing allows the consumer to develop perceived knowledge about the brand. According to results of present study revealed that most of the advancement and improvements in its people are accepting the new ways of the marketing than traditional marketing. Present research study revealed that major challenges faced in digital marketing are trained staff, technology, creative content and security for increasing usage of digital marketing. Further the study suggests that to ensure success of digital marketing, staff should be well trained so that they have the right knowledge and expertise to handle as new tools, platforms and trends as they change rapidly.Hence to increase the penetration of digital marketing in India added emphasis needs to be given on improving digital security to protect Privacy and data sharing Regulation and creating awareness about the digital marketing as a costeffective and quantifiable way of marketing.

The corona virus COVID-19 pandemic has enforced to change all aspects of existing marketing and brands to use of digital for marketing communications. Marketing technology helps to enhance the impact of marketing activities. The company have to be reckless and more have more elastic in adapting to the new reality that will have a huge advantage in the market and will become industry leaders. Organizations needs to make Improvement in Social Media Marketing and customer satisfaction such as (services to customer, CRM and after sales service) as it is vital in this new normal's to be recognized as a market front-runner. It will bring additional business, new customers and further it will create and strengthens customer faithfulness for the product.

\section{REFERENCES}

- Allen, E. and Fjermestad, J. (2001) Ecommerce marketing strategies: an integrated framework and case analysis, Logistics Information Management, Vol. 14(1/2):14 - 23 
- Andrew ParsonsMichael ZeisserRobert Waitman, (1998), Organizing today for the digital marketing of tomorrow. Journal of Interactive Marketing, 12(1), 31

- $\quad$ Black ,K. (2013). Business Statistics: For Contemporary Decision Making, India Willey.

- $\quad$ Burrett, T. (2008)."Market online", B \& T Magazine, 58(2682), 44-45.

- Chaffey D and Smith P (2008). EMarketing Excellence: Planning and Optimizing Your Digital Marketing, Routledge. Fourth Edition, 580-593

- Chuck Hemann and Ken Burbay, (2019). Digital Marketing Analytics:Pearson India.

- Gangeshwer (2013). DK, E-Commerce or Internet Marketing: A Business Review from Indian Context", International Journal of - and e-Service, Science and Technology

- Giese, J. L., and Cote, J. A. (2000). Defining consumer satisfaction. Academy of marketing science review, 1(1), 1-22.

- Klein, L. and Quelch, J.A. (1996).The Internet and international marketing', Sloan Management Review, Vol. 37 No. 3, pp. 60-75

- Kotler, P. (2014).Marketing Management, Delhi: Pearson.

- Morris, N. (2009). Understanding digital marketing: marketing strategies for engaging the digital generation. Journal of Direct, Data and Digital Marketing Practice 10, 384-387.

- P. Sathya (2017)A Study on Digital Marketing and its Impact.International Journal of Science and Research (IJSR) ISSN (Online): 2319-7064 Volume 6 Issue 2,PG 866-868.

- Rekha Dahiya and Gayatri (2017).A Research Paper on Digital Marketing Communication and Consumer Buying Decision Process: An Empirical Study in the Indian Passenger Car Market Journal of global marketing issue 2,Marketing challenges \& opportunities in India 73-95
- Vishal Midha(2012) Impact of Consumer Empowerment on Online Trust: An Examination Across Genders, Elsevier International Journal, 12(3), 2012, 198205

- Yasmin, A., Tasneem, S. and Fatema, K. (2015). Effectiveness of digital marketing in the challenging age: An empirical study. International Journal of Management Science and Business Administration, 1(5), 69-80.

- http://en.wikipedia.org/wiki/Affiliate_mar keting

- $\quad$ http://en.wikipedia.org/wiki/Methodology

- http://en.wikipedia.org/wiki/Search_engin e_optimization

- http://lexicon.ft.com/Term?term=digitalmarketing

- http://www.amsreview.org/amsrev/theory /giese00-01.html,

- http://www.businessdictionary.com/defini tion/digital-marketing.html

- http://www.entrepreneur.com/encyclopedi a/affiliate-marketing

- http://www.sas.com/en_us/insights/marke ting/digital-marketing.html

- http://www.simplydigitalmarketing.com/ what-is-digital-marketing

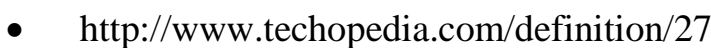
110/digital-marketin 